\title{
Elemental Chemical Composition of Forest Biomass at Different Ages for Energy Purposes
}

\author{
Dimas Agostinho da Silva ${ }^{1}$ (D), Elder Eloy ${ }^{2}$ (D), \\ Braulio Otomar Caron ${ }^{2}$ (D), Paulo Fernando Trugilho ${ }^{3}$ \\ ${ }^{1}$ Universidade Federal do Paraná (UFPR), Curitiba, PR, Brasil \\ ${ }^{2}$ Universidade Federal de Santa Maria (UFSM), Frederico Westphalen, RS, Brasil \\ ${ }^{3}$ Universidade Federal de Lavras (UFLA), Lavras, MG, Brasil
}

\begin{abstract}
This work aimed to evaluate the elemental composition of different biomass components of the forest species Acacia mearnsii De Wild, Eucalyptus grandis W. Hill ex Maiden, Mimosa scabrella Benth and Ateleia glazioviana Baill, at their first, third and fifth year after planting, aiming at bioenergetic use. The biomass elemental composition was determined by quantifying the levels of carbon, hydrogen, nitrogen, sulfur and oxygen. The three ages, the four species, and the four compartments differ in relation to the elementary constituents. The use of trees at any age allows for energy use. The fifth year presents the best carbon and hydrogen values, being the best age for using the biomass energy of the different species. A. mearnsii presents the highest carbon values for the leaf and A. glazioviana presents the highest hydrogen values for all compartments. The leaf is the best compartment for energetic use.
\end{abstract}

Keywords: wood quality, growth, energy. 


\section{INTRODUCTION AND OBJECTIVES}

The definition of evaluation criteria to measure biomass quality is gaining increasing importance, especially in fast-growing forests. In order to evaluate this quality to generate subsidies and to define better use of the biomass, it is essential to identify the chemical, physical and mechanical properties that knowingly alter the final product.

Wood is a heterogeneous material because it is formed by several cells capable of performing specific functions and because it consists of a series of organic and inorganic compounds (Botrel et al., 2010). Wood variability can be explained by several factors, such as the effect of the genetic material used, the planting site, interaction between genotype and environment, and age and spacing, which can significantly affect its chemical, physical, mechanical and anatomical composition, and consequently influence the material's quality for producing energy (Assis et al., 2012).

Age is a factor that changes the characteristics of the source material, mainly due to the marked changes in the woody tissue properties over time, directly reflecting the material's quality for producing energy (Eloy et al., 2017). The choice of the species, the planting site and the analysis of their interaction becomes of fundamental importance, since they reflect in modifying the elemental composition and the physical properties of the wood (Neves et al., 2011), affecting the production and the material's quality for generating energy.

Thus, the biomass use as fuel for energy supply requires characterizing elemental chemical components. The energy released during the combustion process is positively correlated with the carbon and hydrogen contents as a function of the energy value of these elements. In contrast, high oxygen and nitrogen values decrease the calorific value, decreasing the energy potential of the fuel material (Huang et al., 2009; Protásio et al., 2011). In addition, it is desirable that biomass presents low nitrogen and sulfur levels, as these result in increased environmental pollution (Bilgen \& Kaygusuz, 2008; Kumar et al., 2010).

In this context, the present work aims to evaluate the variability of elemental chemical composition in the following different biomass compartments: wood, bark, branch and leaf, of the following forest species:
A. mearnsii De Wild, E. grandis W. Hill ex Maiden, $M$. scabrella Benth and A. glazioviana Baill, in the first, third and fifth year after planting.

\section{MATERIALS AND METHODS}

\subsection{Characterization of the study area}

The work was carried out in an experimental area of the Federal University of Santa Maria, Campus of Frederico Westphalen, RS (UFSM/FW), under geographic coordinates of $27^{\circ} 22^{\prime} \mathrm{S} ; 53^{\circ} 25^{\prime} \mathrm{W}$, at an altitude of $480 \mathrm{~m}$.

According to the Köppen climatic classification, the climate of the region is $\mathrm{Cfa}$, which is subtropical humid with an average annual temperature of $19.1^{\circ} \mathrm{C}$, varying from a maximum of $38^{\circ} \mathrm{C}$ and a minimum of $0{ }^{\circ} \mathrm{C}$, presenting an average annual precipitation of $1,606 \mathrm{~mm}$.

The experiment was carried out using a completely randomized block design. The blocks were characterized by a $4 \times 4 \times 3$ factorial, which is the four forest species (Acacia mearnsii De Wild, Eucalyptus grandis W. Hill ex Maiden, Mimosa scabrella Benth and Ateleia glazioviana Baill), four compartments (wood, bark, branch and leaf) and three periods after planting (first, third and fifth year) in three replications in the subdivided plot scheme, where the plot was represented by the species and the subplot by the age of the data. The block contemplates 16 experimental units, each of which has 45 plants distributed in five rows. The experimental units were divided into three subplots, each consisting of three plants.

The soil of the area is classified as typical dystrophic Red Latosol with a well-drained clayey texture, belonging to the mapping unit of Passo Fundo (Embrapa, 2006). Subsoiling and harrowing operations were carried out in preparation for planting the seedlings. Planting was done manually with subsequent fertilization of $150 \mathrm{~g}$ per NPK seedling in the formulation 8-24-12, in September 2008.

\subsection{Sampling}

Destructive evaluations were carried out in the first year (2009), third year (2011) and fifth year (2013) after planting the experiment, where 144 trees per 
year of evaluation were selected, corresponding to 36 trees per spacing. From these, six discs approximately two centimeters thick were removed in the following positions along the trunk: $0 \%$ (base), $1.30 \mathrm{~m}$ (diameter at breast height - DBH), $25 \%, 50 \% 75 \%$ and $100 \%$ of the total height of the tree. The discs were subsequently packed in plastic bags and transported to the laboratory where they were marked, separated from the wood bark, and then two symmetrically opposite wedges of each disc were sectioned.

The samples of branch and leaf were collected stratified in the plant, that is, in the lower, middle and upper stratum of the tree canopy, in order to obtain a more representative material from the tree canopy. These were identified and taken to circulation drying in greenhouses and renewing the air to obtain the dry matter. The wood, bark, leaf and branch samples were dried at $103 \pm 2{ }^{\circ} \mathrm{C}$ until constant mass.

Leaf sampling for the A. glazioviana species was not computed due to the senescence of the leaf having started prior to the period in which the evaluations were carried out in September.

\subsection{Elemental analysis}

The wood, bark, branch and leaf samples were ground and sieved using the fraction that passed through the 200-mesh sieve and was retained in the 270-mesh sieve. Quantification of the carbon (C), hydrogen $(\mathrm{H})$, nitrogen $(\mathrm{N})$ and sulfur $(\mathrm{S})$ contents in relation to the dry biomass was performed in a duplicate elemental universal analyzer (Vario Micro Cube model). The $2 \mathrm{mg}$ samples were packed in tin capsules and completely incinerated at $1,200^{\circ} \mathrm{C}$. The oxygen content $(\mathrm{O})$ was obtained by the difference in relation to the other elementary components according to Equation 1, as proposed by Protásio et al. (2011).

$$
\mathrm{O}(\%)=100 \%-\mathrm{C}(\%)-\mathrm{H}(\%)-\mathrm{N}(\%)-S(\%)-\mathrm{As}(\%)
$$

O: oxygen content (\%); C: carbon content (\%); H: hydrogen content (\%); N: nitrogen content (\%); S: sulfur content (\%); As: ash content (\%).

\subsection{Data analysis}

The data were submitted to statistical analysis through the "Statistical Analysis System" (Sas, 2003), in which the analysis of variance, regression analysis and the Tukey test averages at $5 \%$ probability of error were performed.

The estimated regression equations were elaborated from the statistical difference between the three evaluation periods for the specific biomass compartments in each elementary chemical constituent. The inferences were only generated for the means when this difference between the years did not occur.

\section{RESULTS AND DISCUSSION}

Analysis of variance revealed a significant difference for the elementary constituents among the four forest species, between the three evaluated periods and among the four biomass compartments studied. Likewise, this characteristic was observed for the species vs. compartment interactions and for year vs. compartment in the elementary constituents of carbon and oxygen. This also occurred for the triple interaction species $x$ compartment $\times$ year for hydrogen, nitrogen and sulfur.

These differences observed in the interactions related to the chemical composition of the biomass within a single tree are related to age, genetic factors and ecological conditions of the environment, which provide variations in the response to the formation of young wood and adult wood. It is clear that chemical properties are subject to substantial initial variations in juvenile wood, but tend to stabilize as adult wood begins to form (Santana et al., 2012). For Eloy et al. (2014), factors related to the structural composition of wood influence its energy potential, mainly with respect to the chemical and elemental constitution.

In relation to the oxygen content, the highest values in the first evaluation year were reported for wood in the four species studied, reaching the mean value of $49.64 \%$ for $A$. mearnsii, which did not differ statistically from the other species; while $E$. grandis was superior to the other species for the bark and branch compartments (Table 1). This high value of oxygen content is not desired when the biomass is intended to be consumed for energy, because according to Protásio et al. (2011), an increase in oxygen content and a decrease in the hydrogen or carbon content tends to decrease the calorific value of the biomass. However, it is necessary to mention that oxygen is an essential element to promote material combustion. 
Table 1. Mean values for the elementary constituents of wood, bark, branch and leaf of the four forest species in the first year after planting.

\begin{tabular}{|c|c|c|c|c|c|}
\hline \multirow{2}{*}{$\begin{array}{l}\text { Elementary } \\
\text { constituent }\end{array}$} & \multirow{2}{*}{ Species } & \multicolumn{4}{|c|}{ Component } \\
\hline & & Wood & Bark & Branch & Leaf \\
\hline \multirow{4}{*}{ Carbon } & A. mearnsii & $43.77 \mathrm{abB}$ & $47.39 \mathrm{aA}$ & $48.31 \mathrm{aA}$ & $47.92 \mathrm{aA}$ \\
\hline & M. scabrella & $44.50 \mathrm{aC}$ & $44.93 \mathrm{bBC}$ & $46.17 \mathrm{bAB}$ & $46.75 \mathrm{abA}$ \\
\hline & E. grandis & $44.05 \mathrm{abB}$ & $37.33 \mathrm{cC}$ & $44.12 \mathrm{cB}$ & $45.83 \mathrm{bA}$ \\
\hline & A. glazioviana & $43.00 \mathrm{bB}$ & $44.13 \mathrm{bAB}$ & $44.97 \mathrm{cA}$ & - \\
\hline \multirow{4}{*}{ Hydrogen } & A. mearnsii & $5.74 \mathrm{bAB}$ & 5.29 bC & $5.82 \mathrm{bA}$ & $5.63 \mathrm{aB}$ \\
\hline & M. scabrella & $5.76 \mathrm{bA}$ & $5.43 \mathrm{bB}$ & $5.61 \mathrm{cA}$ & $5.78 \mathrm{aA}$ \\
\hline & E. grandis & $5.73 \mathrm{bA}$ & $4.15 \mathrm{cC}$ & $5.25 \mathrm{~dB}$ & $5.35 \mathrm{bB}$ \\
\hline & A. glazioviana & $6.00 \mathrm{aA}$ & $5.93 \mathrm{aA}$ & $6.06 \mathrm{aA}$ & - \\
\hline \multirow{4}{*}{ Nitrogen } & A. mearnsii & $0.82 \mathrm{bD}$ & $2.04 \mathrm{cC}$ & $2.28 \mathrm{bB}$ & $3.01 \mathrm{aA}$ \\
\hline & M. scabrella & $0.91 \mathrm{bD}$ & $2.28 \mathrm{bB}$ & $1.87 \mathrm{cC}$ & $2.97 \mathrm{aA}$ \\
\hline & E. grandis & $0.69 \mathrm{cD}$ & $1.05 \mathrm{dC}$ & $1.33 \mathrm{~dB}$ & $2.59 \mathrm{bA}$ \\
\hline & A. glazioviana & $1.70 \mathrm{aC}$ & $3.96 \mathrm{aA}$ & $3.12 \mathrm{aB}$ & - \\
\hline \multirow{4}{*}{ Oxygen } & A. mearnsii & $49.64 \mathrm{aA}$ & $45.23 \mathrm{cB}$ & $43.52 \mathrm{cC}$ & $43.43 \mathrm{bC}$ \\
\hline & M. scabrella & $48.78 \mathrm{aA}$ & $47.26 \mathrm{bAB}$ & $46.28 \mathrm{bB}$ & $44.36 \mathrm{abC}$ \\
\hline & E. grandis & $49.49 \mathrm{aA}$ & $57.45 \mathrm{aB}$ & $49.26 \mathrm{aA}$ & $46.17 \mathrm{aC}$ \\
\hline & A. glazioviana & $49.23 \mathrm{aA}$ & $45.88 \mathrm{bcB}$ & $45.74 \mathrm{bB}$ & - \\
\hline \multirow{4}{*}{ Sulfur } & A. mearnsii & $0.028 \mathrm{aA}$ & $0.046 \mathrm{bA}$ & $0.067 \mathrm{bA}$ & $0.013 \mathrm{bA}$ \\
\hline & M. scabrella & $0.056 \mathrm{aB}$ & $0.100 \mathrm{aAB}$ & $0.071 \mathrm{bB}$ & $0.140 \mathrm{aA}$ \\
\hline & E. grandis & $0.035 \mathrm{aA}$ & $0.028 \mathrm{bA}$ & $0.035 \mathrm{cA}$ & $0.075 \mathrm{abA}$ \\
\hline & A. glazioviana & $0.087 \mathrm{aA}$ & $0.085 \mathrm{aA}$ & $0.111 \mathrm{aA}$ & - \\
\hline
\end{tabular}

Means followed by the same lowercase letter in the column compare the species, and uppercase in the line compare the biomass compartments, they do not differ from each other at $5 \%$ probability of error, according to the Tukey test; -: not evaluated.

The highest average carbon values were generally observed for A. mearnsii in the branch compartment (48.31\%), not differing from leaf and bark. This characteristic was verified for A. glazioviana for hydrogen and nitrogen contents, differing in all evaluated biomass compartments, as well as for the branch $(6.06 \%)$ and bark (3.96\%) compartments, respectively, which was higher in the other species for hydrogen, whereas it was different for nitrogen between compartments (bark $>$ branch $>$ wood) (Table 1). The elemental chemical composition values of the wood observed in this work are in accordance with those reported in the literature for the Eucalyptus genus, of approximately $48 \%$ carbon, $6 \%$ hydrogen, $45 \%$ oxygen, $0.15 \%$ nitrogen and $0.01 \%$ sulfur (Protásio et al., 2011; Neves et al., 2011).

When a high carbon-nitrogen relationship is observed, we conclude that these imply a smaller amount of nitrogen to be released into the environment after biomass combustion. The carbon dioxide $\left(\mathrm{CO}_{2}\right)$ fixed in the biomass and released into the atmosphere by the combustion process is dependent on external factors to the process, and the release rate is mainly determined by the temperature and humidity of the combustible material, and the carbon-nitrogen relationship of biomass (Schneider et al., 2005). Besides, the lower this relationship, the faster the $\mathrm{CO}_{2}$ releases into the atmosphere during combustion; which is not desirable since this gas is one of the responsibles for potentiating the greenhouse effect (Sanquetta et al., 2014).

Variation of the elementary properties of the forest stand in the third year of age was very similar to the first year. A. mearnsii presented the highest carbon values for all compartments, ranging from $45.10 \%$ for wood to $49.40 \%$ for leaf, which showed the highest values for all species studied (Table 2). Thus, when considering using wood as an energy source, it should 
be noted that from the carbon percentage present in the wood, much of this element reacts with hydrogen and oxygen when subjected to the carbonization process, where it becomes volatile and consequent formation of non-condensable gases and condensable gases occurs (Santos et al., 2013). Thus, only a fraction can be considered as fixed carbon which is stable and does not decompose under inert atmospheres.

Furthermore, the hydrogen and nitrogen contents had the highest average values for A. glazioviana standing out in all compartments, with 5.94\% for bark and branches, and $3.66 \%$ for bark, respectively. For oxygen, the highest mean values were reported for wood in the four species studied, with $48.93 \%$ for M. scabrella, and not differing from A. mearnsii and E. grandis (Table 2). When comparing these to the literature, in determining the variability in the characteristics of E. grandis and E. urophylla wood used as energy source, Santana et al. (2012) found higher average values for carbon $(48.72 \%)$ and hydrogen (6.55\%) than those observed in this work and lower nitrogen $(0.12 \%)$ and oxygen (44.57\%) values.

Considering the different compartments for the fifth year, it was observed that leaf generally presented higher carbon, hydrogen, nitrogen and sulfur values for all species except for A. glazioviana, as this compartment was not evaluated. This same behavior was reported for wood in relation to oxygen. Likewise, when comparing different species, the highest values of the wood, bark and branches were reported for A. glazioviana species regarding hydrogen and nitrogen elemental components, and E. grandis and M. scabrella in relation to the oxygen and sulfur, respectively (Table 3). This variability observed in forest biomass can be explained by several factors, such as species, development stage, nutritional status, edaphoclimatic conditions, and with the part of the plant considered, this can significantly affect its chemical composition and consequently influence the material's quality for producing energy (Ratuchne et al., 2016).

Table 2. Mean values for the elementary constituents of wood, bark, branch and leaf of the four forest species in the third year after planting.

\begin{tabular}{|c|c|c|c|c|c|}
\hline \multirow{2}{*}{$\begin{array}{l}\text { Elementary } \\
\text { constituent }\end{array}$} & \multirow{2}{*}{ Species } & \multicolumn{4}{|c|}{ Component } \\
\hline & & Wood & Bark & Branch & Leaf \\
\hline \multirow{4}{*}{ Carbon } & A. mearnsii & $45.10 \mathrm{aC}$ & $47.94 \mathrm{aB}$ & $47.39 \mathrm{aB}$ & $49.40 \mathrm{aA}$ \\
\hline & M. scabrella & $44.72 \mathrm{aB}$ & $44.43 \mathrm{bB}$ & $46.62 \mathrm{aA}$ & $46.53 \mathrm{bA}$ \\
\hline & E. grandis & $44.71 \mathrm{aB}$ & $38.23 \mathrm{cC}$ & $43.94 \mathrm{cB}$ & $47.08 \mathrm{bA}$ \\
\hline & A. glazioviana & $45.04 \mathrm{aAB}$ & $43.65 \mathrm{bB}$ & $45.29 \mathrm{bA}$ & - \\
\hline \multirow{4}{*}{ Hydrogen } & A. mearnsii & $5.79 \mathrm{abB}$ & $5.49 \mathrm{bC}$ & $5.91 \mathrm{abB}$ & $6.28 \mathrm{aA}$ \\
\hline & M. scabrella & $5.55 \mathrm{cBC}$ & $5.42 \mathrm{bC}$ & $5.73 \mathrm{bB}$ & $6.03 \mathrm{bA}$ \\
\hline & E. grandis & $5.73 \mathrm{bA}$ & $4.45 \mathrm{cC}$ & $5.44 \mathrm{cB}$ & $5.88 \mathrm{bA}$ \\
\hline & A. glazioviana & $5.92 \mathrm{aA}$ & $5.94 \mathrm{aA}$ & $5.94 \mathrm{aA}$ & - \\
\hline \multirow{4}{*}{ Nitrogen } & A. mearnsii & $0.80 \mathrm{bC}$ & $1.79 \mathrm{cB}$ & $1.62 \mathrm{cB}$ & $3.07 \mathrm{bA}$ \\
\hline & M. scabrella & $0.74 \mathrm{bD}$ & $2.19 \mathrm{bB}$ & $1.85 \mathrm{bC}$ & $3.55 \mathrm{aA}$ \\
\hline & E. grandis & $0.48 \mathrm{cD}$ & $1.09 \mathrm{~dB}$ & $0.74 \mathrm{dC}$ & $2.72 \mathrm{bA}$ \\
\hline & A. glazioviana & $2.07 \mathrm{aC}$ & $3.66 \mathrm{aA}$ & $2.44 \mathrm{aB}$ & - \\
\hline \multirow{4}{*}{ Oxygen } & A. mearnsii & $48.27 \mathrm{abA}$ & $44.74 \mathrm{cB}$ & $45.04 \mathrm{bB}$ & $41.14 \mathrm{bC}$ \\
\hline & M. scabrella & $48.93 \mathrm{aA}$ & $47.77 \mathrm{bA}$ & $45.70 \mathrm{bB}$ & $43.54 \mathrm{aC}$ \\
\hline & E. grandis & $48.92 \mathrm{aB}$ & $56.19 \mathrm{aA}$ & $49.86 \mathrm{aB}$ & $44.21 \mathrm{aC}$ \\
\hline & A. glazioviana & $46.93 \mathrm{bA}$ & $46.67 \mathrm{bA}$ & $46.27 \mathrm{bA}$ & - \\
\hline \multirow{4}{*}{ Sulfur } & A. mearnsii & $0.037 \mathrm{bB}$ & $0.042 \mathrm{cB}$ & $0.041 \mathrm{cB}$ & $0.112 \mathrm{bA}$ \\
\hline & M. scabrella & $0.060 \mathrm{bC}$ & $0.181 \mathrm{aB}$ & $0.103 \mathrm{aC}$ & $0.363 \mathrm{aA}$ \\
\hline & E. grandis & $0.156 \mathrm{aA}$ & $0.046 \mathrm{cB}$ & $0.014 \mathrm{~dB}$ & $0.118 \mathrm{bA}$ \\
\hline & A. glazioviana & $0.036 \mathrm{bA}$ & $0.076 \mathrm{bA}$ & $0.059 \mathrm{bA}$ & - \\
\hline
\end{tabular}

Means followed by the same lowercase letter in the column compare the species, and uppercase in the line compare the biomass compartments, they do not differ from each other at $5 \%$ probability of error, according to the Tukey test; -: not evaluated. 
Table 3. Mean values for the elementary constituents of wood, bark, branch and leaf of the four forest species in the fifth year after planting.

\begin{tabular}{|c|c|c|c|c|c|}
\hline \multirow{2}{*}{$\begin{array}{l}\text { Elementary } \\
\text { constituent }\end{array}$} & \multirow{2}{*}{ Species } & \multicolumn{4}{|c|}{ Component } \\
\hline & & Wood & Bark & Branch & Leaf \\
\hline \multirow{4}{*}{ Carbon } & A. mearnsii & $45.32 \mathrm{aC}$ & $48.93 \mathrm{aB}$ & $46.79 \mathrm{aB}$ & $51.67 \mathrm{aA}$ \\
\hline & M. scabrella & $45.62 \mathrm{aAB}$ & $44.60 \mathrm{bB}$ & $45.23 \mathrm{bB}$ & $46.73 \mathrm{bA}$ \\
\hline & E. grandis & $45.26 \mathrm{aB}$ & $37.80 \mathrm{cD}$ & $43.38 \mathrm{cC}$ & $48.20 \mathrm{bA}$ \\
\hline & A. glazioviana & $45.07 \mathrm{aB}$ & $43.69 \mathrm{bB}$ & $46.55 \mathrm{aA}$ & - \\
\hline \multirow{4}{*}{ Hydrogen } & A. mearnsii & $5.70 \mathrm{bB}$ & $5.29 \mathrm{bC}$ & $5.79 \mathrm{abB}$ & $6.92 \mathrm{aA}$ \\
\hline & M. scabrella & $5.59 \mathrm{bB}$ & $5.50 \mathrm{bB}$ & $5.61 \mathrm{bB}$ & $6.07 \mathrm{bA}$ \\
\hline & E. grandis & $5.67 \mathrm{bB}$ & $4.38 \mathrm{cD}$ & $5.32 \mathrm{cC}$ & $6.09 \mathrm{bA}$ \\
\hline & A. glazioviana & $6.02 \mathrm{aA}$ & $6.00 \mathrm{aA}$ & $6.02 \mathrm{aA}$ & - \\
\hline \multirow{4}{*}{ Nitrogen } & A. mearnsii & $0.49 \mathrm{cD}$ & $1.67 \mathrm{cB}$ & $1.38 \mathrm{cC}$ & $2.81 \mathrm{bA}$ \\
\hline & M. scabrella & $0.68 \mathrm{bD}$ & $2.08 \mathrm{bB}$ & $1.69 \mathrm{bC}$ & $3.77 \mathrm{aA}$ \\
\hline & E. grandis & $0.29 \mathrm{dD}$ & $0.68 \mathrm{dC}$ & $0.96 \mathrm{~dB}$ & $2.54 \mathrm{bA}$ \\
\hline & A. glazioviana & $1.35 \mathrm{aC}$ & $3.77 \mathrm{aA}$ & $2.32 \mathrm{aB}$ & - \\
\hline \multirow{4}{*}{ Oxygen } & A. mearnsii & $48.49 \mathrm{aA}$ & $44.10 \mathrm{cC}$ & $46.02 \mathrm{bcB}$ & $38.48 \mathrm{bD}$ \\
\hline & M. scabrella & $48.08 \mathrm{aA}$ & $47.67 \mathrm{bA}$ & $47.42 \mathrm{bA}$ & $43.18 \mathrm{aB}$ \\
\hline & E. grandis & $48.77 \mathrm{aB}$ & $57.12 \mathrm{aA}$ & $50.34 \mathrm{aB}$ & $42.93 \mathrm{aC}$ \\
\hline & A. glazioviana & $47.54 \mathrm{aA}$ & $46.48 \mathrm{bAB}$ & $45.06 \mathrm{cB}$ & - \\
\hline \multirow{4}{*}{ Sulfur } & A. mearnsii & $0.002 \mathrm{aB}$ & $0.014 \mathrm{cB}$ & $0.013 \mathrm{bB}$ & $0.125 \mathrm{bA}$ \\
\hline & M. scabrella & $0.030 \mathrm{aC}$ & $0.143 \mathrm{aB}$ & $0.055 \mathrm{aC}$ & $0.249 \mathrm{aA}$ \\
\hline & E. grandis & $0.004 \mathrm{aB}$ & $0.013 \mathrm{cB}$ & $0.012 \mathrm{bB}$ & $0.246 \mathrm{aA}$ \\
\hline & A. glazioviana & $0.024 \mathrm{aA}$ & $0.057 \mathrm{bA}$ & $0.053 \mathrm{aA}$ & - \\
\hline
\end{tabular}

Means followed by the same lowercase letter in the column compare the species, and uppercase in the line compare the biomass compartments, they do not differ from each other at $5 \%$ probability of error, according to the Tukey test; -: not evaluated.

The variability in the wood can be explained by several factors, such as the effect of the genetic material used, the planting site, interaction between genotype and environment, age and spacing, which can significantly affect its chemical, physical, mechanical and anatomical composition, and consequently influence the material's quality for producing energy (Assis et al., 2012).

The use of biomass as biofuel for energy supply requires its elementary characterization, mainly because when biomass is destined for producing energy, it must contain smaller amounts of oxygen and nitrogen and high carbon and hydrogen levels, since these elementary components have direct correlations with the gross calorific value (Obernberger et al., 2006; Huang et al., 2009, Protásio et al., 2011).

When analyzing the biomass components and their potential to be used as an energy source, and not only considering using the wood, but all the compartments, the
A. mearnsii and A. glazioviana species generally presented the best carbon and hydrogen values, respectively, resulting in a greater potential for power generation. The E. grandis species was the least recommended species for this purpose, in view of the same criteria, since it generally presents the highest average oxygen values when compared to the other species, mainly in the bark and branch compartments.

For Protásio et al. (2011), an increase of approximately $515 \mathrm{kcal} \mathrm{kg}^{-1}$ in the biomass calorific value occurs for every $1 \%$ increase in the hydrogen content. They also observed that every $1 \%$ increase in the carbon content causes an increase of $64.14 \mathrm{kcal} \mathrm{kg}^{-1}$ in the biomass calorific value. For the same authors, low hydrogen values in the wood composition result in a high carbon-hydrogen relationship; which is undesirable when it is aimed for energy production, because small increases in the hydrogen content provide high gains in the biomass calorific value. 
When the significant equations were analyzed over time for the fifth year after planting, there was an increasing tendency in the carbon content for the bark and the leaf of A. mearnsii (Figure 1A), for E. grandis leaf (Figure 1B) and for A. glazioviana wood (Figure 1C). Santana et al. (2012), who also found higher carbon values in older trees, suggested that carbon levels tend to increase as tree size increases, as well as being directly proportional to biomass production. For the same authors, this significant increase in the carbon content with the advancing age is much desired when the objective is to destine the biomass to produce energy, since it positively contributes to the calorific power.

Thus, it is observed that when the growth tendency of a certain element occurs, the others behave inversely proportionally. This corroborates Assis et al. (2012), who concluded that the increase in the carbon content of the fuel is associated with a decrease in the hydrogen, nitrogen and oxygen levels, since these elements combine and are volatilized, thus justifying the observed trends.

In the same way that increasing trends over time were observed for the carbon content in A. mearnsii (Figure 1A) and E. grandis (Figure 1B) leaf compartments, this characteristic was also observed for the hydrogen content in the E. grandis (Figure 1D), A. mearnsii (Figure 1E) and M. scabrella (Figure 1F) leafs. These positive trends over time are highly desired for an energetic material and corroborate with Santana et al. (2012) in working with trees between 34 and 48 months, who observed the best values of these elements which therefore suggested better energy values and less impact to the environment.

Although the hydrogen content presents statistical difference with the age of the trees only for the leaf, it is emphasized that it significantly contributes to the increase in the calorific value of the fuel (Demirbas \& Demirbas, 2004; Huang et al., 2009; Protásio et al. al., 2011). Thus, it is recommended to consider the proportion of other elemental chemical constituents for selecting and evaluating wood in the considered ages, with a view toward its energetic use.

In general, it is expected that wood with higher carbon content has a positive relationship with higher thermal resistance, and consequently a longer energy supply, due to the chemical nature of this element. However, it must be emphasized that hydrogen is the chemical element with the greatest capacity to provide energy from wood combustion. The vast majority of fuels (other than nuclear fuels) depends on the thermal effect resulting from the combustion of carbon and hydrogen. On the other hand, the presence of oxygen in the wood offers the disadvantage of diminishing its value as a fuel (Santos et al., 2013).

In relation to the significant equations for the nitrogen content, there is a decreasing tendency in the wood, bark and branches of A. mearnsii (Figure 2A) and M. scabrella (Figure 2B), as well as in the wood and bark of $E$. grandis (Figure 2C) and the bark and branches of A. glazioviana (Figure 2D). Likewise, this trend was observed for the oxygen content in leaf from the A. mearnsii (Figure 2E), M. scabrella (Figure 2F) and E. grandis (Figure 2G) species. This variation found in the nitrogen content may be associated with physiological activity, since smaller trees have a higher percentage of sapwood, as it is through this active region that the necessary compounds for the survival of the trees are translocated, and therefore the physiological activities are more intense in these than older trees. The significant values found show that nitrogen levels tend to be higher in trees with lower ages.

This trend of decreasing the nitrogen content in the wood with the increase in age can occur due to the genetic and consequently physiological differences of the trees, as well as the aspects related to soil fertility and fertilization, which was also verified by Neves et al. (2011) when studying Eucalyptus clones. However, the nitrogen concentrations observed in this study were higher than those found in the literature.

Regarding the sulfur content, there is a decreasing trend of A. mearnsii (Figure 1G) and M. scabrella (Figure 1J), and the E. grandis branches (Figure 1I). For the bark and branches of A. glazioviana (Figure $1 \mathrm{H}$ ), there was a growing trend up to the third year, and a subsequent decrease in the sulfur content. Although they did not verify a significant difference for the sulfur content due to the size of the trees, Santana et al. (2012) concluded that the levels are conditioned to the type of species and the conditions of each planting site. These sulfur values are in agreement with those acceptable by the steel industry, which are all below 0.5\% (Assis et al., 2012). 

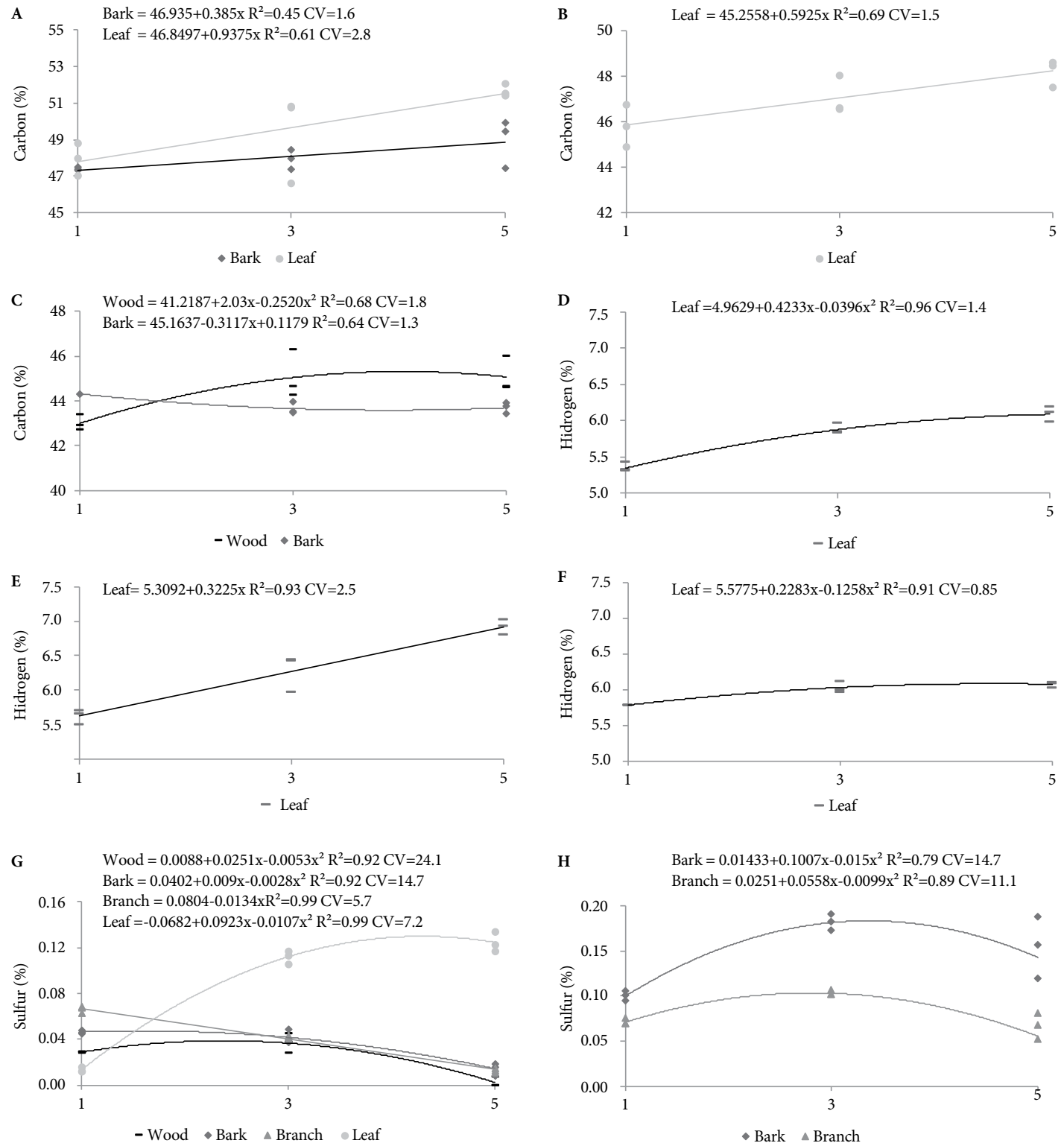

H Bark $=0.01433+0.1007 \mathrm{x}-0.015 \mathrm{x}^{2} \mathrm{R}^{2}=0.79 \mathrm{CV}=14.7$
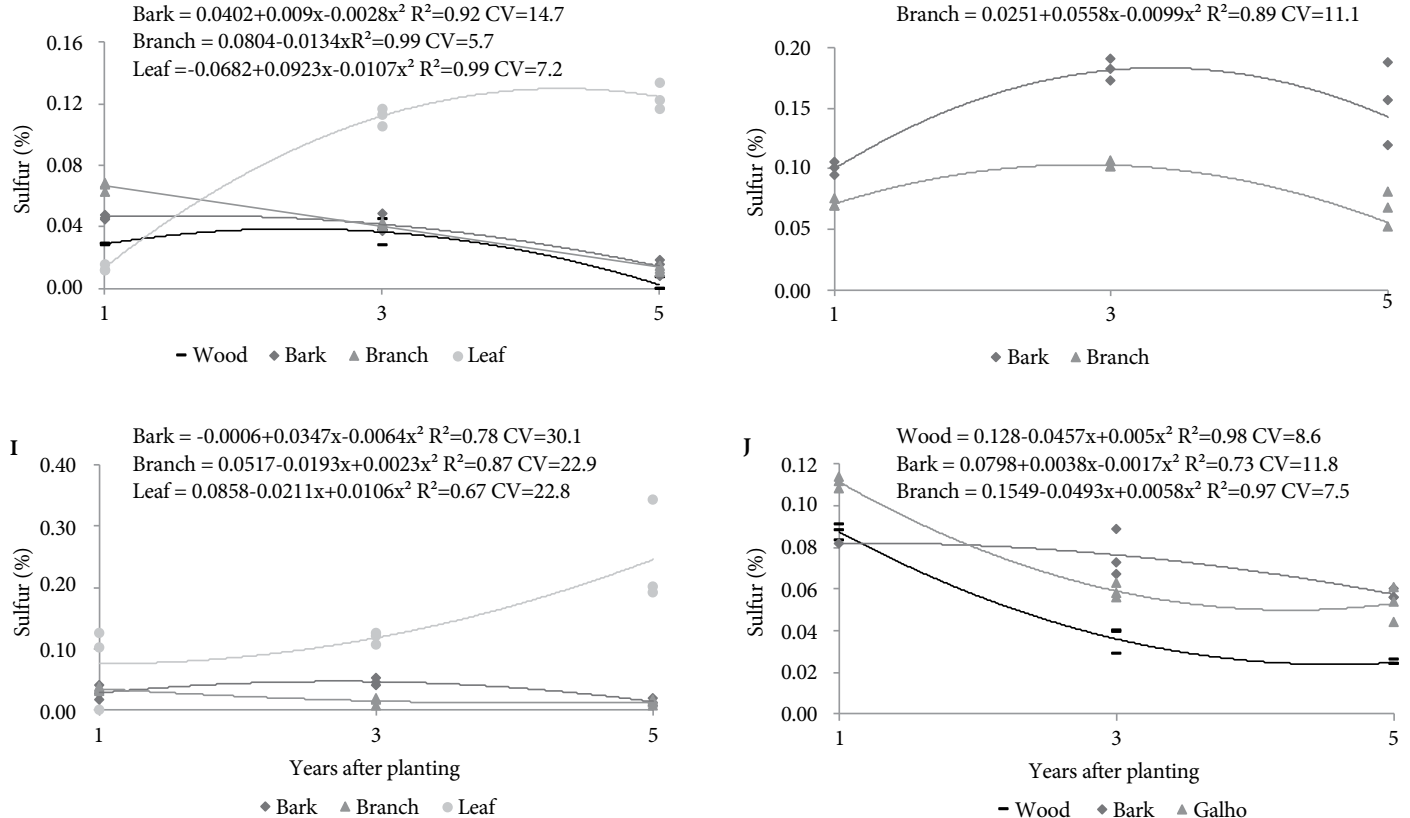

Figure 1. Estimated regression equations $\left({ }^{*}\right)$ for the carbon content of the different biomass compartments of the species A. mearnsii (A), E. grandis (B), A. glazioviana (C), for the hydrogen content in the leaf of E. grandis (D), A. mearnsii (E) and M. scabrella (F) and for the sulfur content in the four biomass compartments of A. mearnsii (G), A. glazioviana $(\mathrm{H})$, E. grandis (I) and M. scabrella $(\mathrm{J})$ in the first, third and fifth year after planting. 

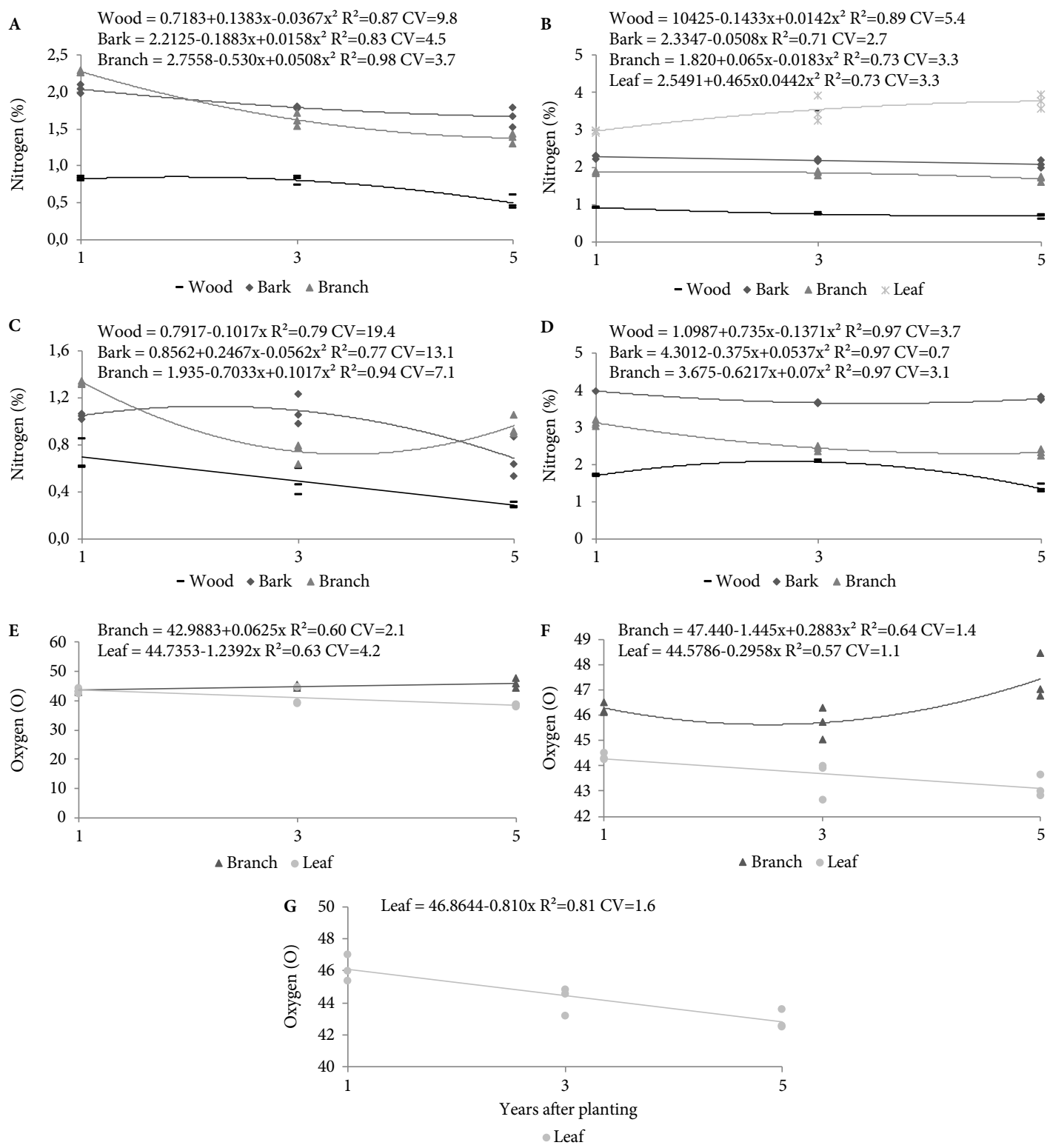

Figure 2. Estimated regression equations $\left(^{*}\right)$ for the nitrogen content in the different biomass compartments of the species A. mearnsii (A), M. scabrella (B), E. grandis (C) and A. glazioviana (D); and for the oxygen content in the branch and leaf compartments of the species A. mearnsii (E), M. scabrella (F), and leaf for E. grandis (G) in the first, third and fifth year after planting.

The sulfur and nitrogen elements contribute relatively little to the energy release of a fuel (Bilgen \& Kaygusuz, 2008), showing a negative correlation with the calorific value (Bilang \& Kaygusuz, 2008; Huang et al., 2009; Kumar et al., 2010), while high levels can cause environmental pollution when released into the atmosphere after the complete combustion of the fuel. Even though wood is a low-sulfur fuel, smaller percentages are always desired, thus avoiding the formation and emission of sulfur gases into the atmosphere.

This study corroborates the results of Santana et al. (2012), who found lower nitrogen concentrations at a more advanced age, together with minimum sulfur concentrations, indicating that the studied species can be used for energy production. The use of wood as fuel for energy supply requires elementary 
characterization, in particular to determine the amounts of nitrogen and sulfur.

The high concentrations of these two elements have a negative impact on the environment and human health. Nitrogen is directly related to the emission of NOx components (toxic nitrogen oxides), corrosion and ash deposition (Assis et al., 2018). In contrast, sulfur is related to the emission of sulfur dioxide $\left(\mathrm{SO}_{2}\right)$ and formation of acid rain, and consequently corrosion (Bilgen \& Kaygusuz, 2008). In addition, when sulfur is present in high concentrations it can cause the formation of $\mathrm{FeCl}_{2}$ and $\mathrm{ZnCl}_{2}$, which are corrosive components in boilers (Telmo et al., 2010).

As it can be observed in most woods, low sulfur concentrations do not impede their energy use, similar to other biomasses reported in the literature (Neves et al., 2011; Bufalino et al., 2012). Thus, low proportions of this component suggest that the biomass compartments studied are environmentally adequate for energy production (Pattiya, 2011).

Age was a factor that influenced the characteristics of the source material. This change over time is mainly motivated by the marked modifications in the woody tissue characteristics, reflecting in the material's quality for producing energy. Thus, it is of fundamental importance to choose the species and the planting site, as well as the analysis of their interaction, as these reflect in changes in the elemental composition influencing the production and quality of the material for producing energy.

\section{CONCLUSIONS}

The three ages induced a significant effect on the elemental constituents of biomass, generating:

- Increased distribution of the hydrogen content of $A$. mearnsii, M. scabrella and E. grandis leaf, and for the carbon content of $A$. mearnsii bark and leaf, and for E. grandis and A. glazioviana leaf.

- A decreased distribution of the nitrogen content in the wood, bark and branches of A. mearnsii and M. scabrella, in the wood and bark of E. grandis and in the branches of A. glazioviana. For the oxygen content in the leaf of A. mearnsii, M. scabrella and $E$. grandis, and for the sulfur content in the wood, bark and branches of A. mearnsii and A. glazioviana, and for E. grandis branches.
- The use of trees at any age enables energetic use; however, the fifth year presents the best carbon and hydrogen values, being the best age for the energetic use of the biomass of these different species.

The four forest species and the four compartments of the biomass differ in relation to the elementary constituents.

In general, the higher values of the elemental constituents of hydrogen and nitrogen were verified for A. glazioviana, those of carbon in general for A. mearnsii, those of sulfur for M. scabrella and the highest oxygen values were reported for E. grandis.

The biomass of the A. mearnsii and A. glazioviana species generally has greater potential for energy purposes, considering the carbon and hydrogen values. The E. grandis species is less recommended for this purpose, considering the same criteria.

\section{SUBMISSION STATUS}

Received: 19 Apr., 2016

Accepted: 12 Sept., 2018

\section{CORRESPONDENCE TO}

\section{Elder Eloy}

Universidade Federal de Santa Maria (UFSM),

Rua Sete de Setembro, s/n, CEP 98400-000,

Frederico Westphalen, RS, Brasil

e-mail: eloyelder@yahoo.com.br

\section{FINANCIAL SUPPORT}

National Council for Scientific and Technological Development (CNPq - Brazil).

\section{REFERÊNCIAS}

Assis CO, Trugilho PF, Goulart SL, Assis MR, Bianchi ML. Efeito da aplicação de nitrogênio na produção e qualidade da madeira e carvão vegetal de um híbrido de Eucalyptus grandis $\times$ Eucalyptus urophylla. Floresta e Ambiente 2018; 25(1): e00117914. 10.1590/2179-8087.117914

Assis MR, Protásio TP, Assis CO, Trugilho PF, Santana WMS. Qualidade e rendimento do carvão vegetal de um clone híbrido de Eucalyptus grandis $\times$ Eucalyptus urophylla. Pesquisa Florestal Brasileira 2012; 32(71): 291 302. 10.4336/2012.pfb.32.71.291 
Bilgen S, Kaygusuz K. The calculation of the chemical exergies of coal-based fuels by using the higher heating values. Applied Energy 2008; 85(8): 776-785. 10.1016/j. apenergy.2008.02.001

Botrel MCG, Trugilho PF, Rosado SCS, Silva JRM. Seleção de clones de Eucalyptus para biomassa florestal e qualidade da madeira. Scientia Forestalis 2010; 38(86): 237-245.

Bufalino L, Protásio TP, Couto AM, Nassur OAC, Sá VA, Trugilho PF et al. Caracterização química e energética para aproveitamento da madeira de costaneira e desbaste de cedro australiano. Pesquisa Florestal Brasileira 2012; 32(70): 129-137. 10.4336/2012.pfb.32.70.13

Demirbas A, Demirbas HA. Estimating the calorific values of lignocellulosic fuels. Journal Energy, Exploration \& Exploitation 2004; 22(2): 135-143. $10.1260 / 0144598041475198$

Eloy E, Caron BO, Silva DA, Schmidt D, Trevisan $\mathrm{R}$, Behling $\mathrm{A}$ et al. Influência do espaçamento nas características energéticas de espécies arbóreas em plantios de curta rotação. Revista Árvore 2014; 38(3): 551-559. 10.1590/S0100-67622014000300018

Eloy E, Silva DA, Caron BO, Elli EF, Schwerz F. Age and tree spacing and their effects on energy properties of Ateleia glazioviana. Ciência Rural 2017; 47(9): e20160378. 10.1590/0103-8478cr20160378

Empresa Brasileira de Pesquisa Agropecuária - Embrapa. Sistema brasileiro de classificação de solos. 2nd ed. Brasília, DF; 2006.

Huang C, Han L, Yang Z, Liu X. Ultimate analysis and heating value prediction of straw by near infrared spectroscopy. Waste Management 2009; 29(6): 1793-1797. 10.1016/j.wasman.2008.11.027

Kumar R, Pandey KK, Chandrashekar N, Mohan S. Effect of tree-age on calorific value and other fuel properties of Eucalyptus hybrid. Journal of Forestry Research 2010; 21(4): 514-516. 10.1007/s11676-010-0108-x

Neves TA, Protásio TP, Couto AM, Trugilho PF, Silva VO, Vieira CMM. Avaliação de clones de Eucalyptus em diferentes locais visando à produção de carvão vegetal. Pesquisa Florestal Brasileira 2011; 31(68): 319-330. 10.4336/2011.pfb.31.68.319
Obernberger I, Brunner T, Bärnthaler G. Chemical properties of solid biomass fuels significance and impact. Biomass and Bioenergy 2006; 30(11): 973-982. 10.1016/j. biombioe.2006.06.011

Pattiya A. Thermochemical characterization of agricultural wastes from thai cassava plantations. Energy Sources 2011; 33(8): 691-701. 10.1080/15567030903228922

Protásio TP, Bufalino L, Tonoli GHD, Couto AM, Trugilho PF, Guimarães M Jr. Relação entre o poder calorífico superior e os componentes elementares e minerais da biomassa vegetal. Pesquisa Florestal Brasileira 2011; 31(66): 113-122. 10.4336/2011.pfb.31.66.113

Ratuchne LC, Koehler HS, Watzlawick LF, Sanquetta CR, Schamne PA. Estado da arte na quantificação de biomassa em raízes de formações florestais. Floresta e Ambiente 2016; 23(3): 450-462. 10.1590/2179-8087.131515

Sanquetta CR, Behling A, Dalla Corte AP, Simon A, Pscheidt $\mathrm{H}$, Ruza MS et al. Estoques de biomassa e carbono em povoamentos de acácia-negra em diferentes idades no Rio Grande do Sul. Scientia Forestalis 2014; 42(103): 361-370.

Santana WMS, Calegario N, Arantes MDC, Trugilho PF. Effect of age and diameter class on the properties of wood from clonal Eucalyptus. Cerne 2012; 18(1): 1-8. 10.1590/ S0104-77602012000100001

Santos RC, Carneiro ACO, Pimenta AS, Castro RVO, Marinho IV, Trugilho PF et al. Potencial energético da madeira de espécies oriundas de plano de manejo florestal no estado do Rio Grande do Norte. Ciência Florestal 2013; 23(2): 491-502. 10.5902/198050989293

Sas Learning Edition. Getting started with the SAS Learning Edition. Cary; 2003.

Schneider PR, Finger CAG, Giacomelli Sobrinho V, Schneider PSP. Determinação indireta do estoque de biomassa e carbono em povoamentos de acácia-negra (Acacia mearnsii De Wild.). Ciência Florestal 2005; 15(4): 391-402. 10.5902/198050981876

Telmo C, Lousada J, Moreira N. Proximate analysis, backwards stepwise regression between gross calorific value, ultimate and chemical analysis of wood. Bioresource Technology 2010; 101(11): 3808-3815. 10.1016/j. biortech.2010.01.021 